\title{
PHYSICAL ACTIVITY AND MENTAL HEALTH: THE ASSOCIATION BETWEEN EXERCISE AND MOOD
}

\author{
Marco Aurélio Monteiro Peluso and Laura Helena Silveira Guerra de Andrade
}

PELUSO MAM et al. Physical activity and mental health: the association between exercise and mood. CLINICS 60(1): 61-70, 2005.

Physical activity is an important public health tool used in the treatment and prevention of various physical diseases, as well as in the treatment of some psychiatric diseases such as depressive and anxiety disorders. However, studies have shown that in addition to its beneficial effects, physical activity can also be associated with impaired mental health, being related to disturbances like "excessive exercise" and "overtraining syndrome". Although the number of reports of the effects of physical activity on mental health is steadily increasing, these studies have not yet identified the mechanisms involved in the benefits and dangers to mental health associated with exercise. This article reviews the information available regarding the relationship between physical activity and mental health, specifically addressing the association between exercise and mood.

KEYWORDS: Mental health. Mood. Sports. Exercise.

Physical activity is recommended to the general population by many medical entities - including the Centers for Disease Control and Prevention (CDC) and the American College of Sports Medicine (ACSM) - because it is considered an important tool for the improvement of public health. ${ }^{1,2}$ Based on the evidence that this type of activity promotes health and is useful for the prevention and treatment of different types of diseases such as heart disease, ${ }^{3-5}$ hypertension, ${ }^{6-8}$ non-insulin-dependent diabetes mellitus, ${ }^{9-}$ ${ }^{11}$ and osteoporosis, ${ }^{12-14}$ the CDC and ACSM have endorsed the following consensus "public health message": "every North American adult should accumulate 30 minutes or more of moderate-intensity physical activity on most, preferably all, days of the week". ${ }^{1}$

As is the case for non-psychiatric diseases, physical activity might be an effective measure for the treatment ${ }^{15-25}$ and even for the prevention ${ }^{1,19,26,27}$ of psychiatric diseases such as depressive and anxiety disorders. In addition, physi-

From the Institute of Psychiatry, Hospital das Clínicas, Faculty of Medicine, University of São Paulo - São Paulo/SP, Brazil.

E-mail: mampeluso@hotmail.com.

Received for publication on April 14, 2004

Accepted for publication on July 13, 2004. cal activity has increasingly been recommended to individuals with or without disease in order to improve their quality of life. On the other hand, physical activity can compromise mental health, especially when performed in a more intense manner.

The understanding of the effects of physical activity on mental health, therefore, has the potential to influence, in various aspects, the clinical practice of a psychologist or psychiatrist, on one hand, as an auxiliary tool in the prevention and treatment of psychiatric diseases, and as a tool in the promotion of a more satisfactory quality of life, or on the other hand, as a cause of problems that require adequate diagnosis and effective treatment.

The present article reviews the information available regarding the relationship between physical activity and mental health, specifically addressing the association between exercise and mood.

\section{METHOD}

Studies that evaluated the association between physical activity and mental health were searched. Only human- 
based studies written in English were selected. Medline database was consulted for articles released from 1990 until 2002, interrelating the following key words (in key words field): "sports", "exercise", "mood," and "depression". This search resulted in 762 references. The titles and then the abstracts were screened, searching for articles with the main focus on the relationship between mood and exercise. All articles that did not have the main focus on this relationship were excluded. Articles with a focus on athletic injuries, personality profiles, athletic performance, drugs (medical or not), and handicapped athletes were excluded as well. This screening resulted in 87 references. Bibliographic references in the selected articles and books on the theme were also consulted. Information about exercise physiology and the effects of physical activity on non-psychiatric disorders was based on the reference section of the latest ACSM position stand on exercise and cardiovascular and muscular fitness. $^{2}$

\section{PHYSICAL ACTIVITY AND IMPROVEMENT OF MENTAL HEALTH}

It has been known for many years that regular physical activity brings benefits to individuals with depressive and anxiety symptoms, ${ }^{15-22}$ a fact confirmed in recent studies. ${ }^{23-}$ ${ }^{25}$ In addition, physical activity improves the quality of life of patients with nonpsychiatric diseases such as peripheral arterial occlusive disease ${ }^{28}$ and fibromyalgia ${ }^{29}$ and helps in the relief of such diverse conditions as nicotine abstinence ${ }^{30}$ and menopause. ${ }^{31}$

The relationship between improvement of mood and exercise, however, does not seem to be universal. Studies have shown that individuals without psychiatric symptoms who regularly exercise experience better moods than those who do not, ${ }^{31-34}$ however, it should be noted that an association between improvement of mood and medium- or long-term physical activity has not consistently been demonstrated for normal individuals. ${ }^{33-36}$ On the other hand, there are studies reporting improvement of various other aspects such as selfesteem, ${ }^{37}$ vitality, ${ }^{38}$ general well-being, and satisfaction with physical appearance. ${ }^{35}$ Evidence also indicates that regular physical activity may protect against the development of depression, ${ }^{1,19,26,27}$ or that physical inactivity might be a risk factor for depression, ${ }^{16}$ but the possible protective effect has not been demonstrated experimentally. ${ }^{35}$

The effects of regular physical activity on mood have mainly been studied using aerobic exercise, ${ }^{38,39}$ but evidence indicates that anaerobic physical activity, such as body building or flexibility training, can also reduce depressive symptoms. ${ }^{18,22,35}$ In contrast, no consensus exists with respect to anxiety symptoms, with some authors reporting that anaerobic activity is as effective as aerobic exercise, ${ }^{17}$ while others do not. ${ }^{21}$

With respect to the acute effects of aerobic physical activity, improvement of depressive $e^{40-45}$ and anxiety ${ }^{19,21,46-48}$ symptoms after a single exercise episode has been reported to occur and to last for some hours or even up to one day, and at least for anxiety symptoms there is evidence that anaerobic exercise (body building) may yield the same effect, which probably is not observed immediately after the end of exercise $\mathrm{e}^{49}$ but rather a few hours later. ${ }^{50}$

\section{PHYSICAL ACTIVITY AND IMPROVEMENT OF MENTAL HEALTH: MECHANISMS}

Various psychological hypotheses have been proposed to explain the beneficial effects of physical activity on mental health, the main being 1) distraction, 2) self-efficacy, and 3) social interaction. The distraction hypothesis ${ }^{15}$ suggests that diversion from unfavorable stimuli leads to an improved mood during and after exercise. The self-efficacy hypothesis ${ }^{20}$ proposes that, since physical exercise can be seen as a challenging activity, the ability to get involved in it in a regular manner might lead to improved mood and self-confidence. With respect to the social interaction hypothesis, ${ }^{51}$ the social relationships commonly inherent in physical activity, as well as the mutual support that occurs among individuals involved in exercise, play an important role in the effects of exercise on mental health.

In addition, physiological hypotheses have also been raised to explain the effects of physical activity on mental health, the two most studied ones being based on 1) monoamines and 2) endorphins. The first hypothesis is supported by the fact that physical activity increases the synaptic transmission of monoamines, ${ }^{15,51}$ which supposedly function in the same manner as antidepressive drugs. ${ }^{52,53}$ Because it would be an oversimplification to state that the efficacy of antidepressives is due to increased synaptic transmission of monoamines, it follows that this hypothesis, although plausible, also seems likewise too simple to explain the improvement of mood associated with physical activity. ${ }^{15,52}$

The second hypothesis, however, is based on the observation that physical activity causes the release of endogenous opioids (endorphins - "endogenous morphines"), basically beta-endorphin. ${ }^{15,51,53}$ Supposedly, the inhibitory effects of these substances on the central nervous system are responsible for the sensation of calm and improved mood experienced after exercise, ${ }^{54}$ but this has yet to be confirmed. Another speculation is the possible relation between increased irritability, restlessness, nervousness, and feelings of frustration reported by physically active individuals when 
withdrawn from exercise ${ }^{55}$ and in a state of endorphin abstinence. ${ }^{54} \mathrm{~A}$ last unclarified point is the fact that some studies $^{54,56}$ have reported that opioid receptor blockers such as naloxone or naltrexone reduce the affective response to exercise, thus favoring a role of endorphins, but there are investigations contradicting this hypothesis. ${ }^{35,41,57}$

No consensus exists regarding the relative importance of the above mentioned hypotheses (both psychological and physiological) in explaining the association between physical activity and mood improvement. A psychobiological model combining all of them is the most probable. ${ }^{35}$ In order to obtain a precise definition of this model, a better understanding of the mechanisms that link physical activity to each of these hypotheses and of the mechanisms that link these hypotheses to improved mood is necessary. This knowledge will probably lead to a model in which psychological and biological factors interact in a specific and concatenate manner, and which varies according to environmental stimuli and the psychological and biological characteristics of each individual.

\section{PHYSICAL ACTIVITY AND MENTAL HEALTH PROBLEMS}

\section{Excessive exercise}

For some individuals, physical activity becomes an obsession, resulting in an exaggerated preoccupation with exercise and excessive training even in the presence of medical counter indications, which can interfere with personal and occupational relationships. ${ }^{58-60}$ Studies on this subject have characterized this condition from the beginning as an analog of anorexia nervosa ${ }^{61}$ or as an addiction, ${ }^{62}$ and investigations have since then been centered on a better definition of its characteristics..$^{59,60,63-65}$ These studies pointed to differences between the characteristics of individuals that present excessive exercise associated to an eating disorder, and individuals that present excessive exercise with no sign of an eating disorder. Moreover, such reports stress that primary excessive exercise is rarely pathologic, since most exercise-dependent individuals show no signs of disease but rather present good mental health. ${ }^{60,63,64}$ However, case reports $^{59}$ leave no doubt regarding the possibilities of significant physical damage caused by excessive exercise.

\section{Muscle dysmorphia}

Physical activity can be associated with a condition of alterations in body image found among some weightlifters and bodybuilders, ${ }^{66-71}$ whereby the individuals, although large and muscular, believe that they are weak and skinny.
In principle, denominations such as "bigamerexia" 66 and "reverse anorexia" 67 have been suggested for this condition. Pope et al., ${ }^{70}$ in order to facilitate further research, proposed the following criteria for the diagnosis of "muscle dysmorphia" based on the DSM-IV ${ }^{72}$ diagnostic criteria for body dysmorphic disorder: 1) excessive preoccupation with the idea that their body is not sufficiently slim (in terms of a low fat content) and muscular; 2) this preoccupation causes discomfort and significant impaired social functioning; 3) this preoccupation cannot be explained by any other psychiatric disorder. In addition to its association with physical activity, evidence indicates a relationship between the presence of muscle dysmorphia and a history of mood, anxiety, and eating disorders ${ }^{71}$, as well as anabolic-androgenic steroid use. ${ }^{67,71}$

\section{Use of anabolic-androgenic steroids}

Since anabolic-androgenic steroids are almost exclusively used by physically active individuals, this represents one more situation in which an association between physical activity and impaired mental health can be observed. The effect of these substances is characterized by significant increases in irritability and aggressiveness and by the occurrence of manic-like and psychotic symptoms - which might provoke some users to commit criminal acts ${ }^{73}$ - as well as of depressive symptoms during periods of abstinence. ${ }^{74-78}$ In addition, it has been suggested that the continuous use of these substances can lead to a condition of dependence. $^{79}$

\section{Intense physical activity and mood disturbances}

Physical activity is not associated only with improvement of mood. There are reports indicating that the mood improvement observed after a moderate level of exercising does not occur after a single session of intense physical exercise; ${ }^{42,80}$ mood can even be worsened compared to the state before exercise ${ }^{81,82}$ which also seems to be the case after a few days of intense physical activity. ${ }^{83}$ On a mediumand long-term basis, mood improvement seems to be associated with moderate-intensity physical activity, ${ }^{84}$ while worsened mood has been reported after high-intensity exercise lasting for 10 days to some weeks. ${ }^{85-94}$

The studies that found these mood disturbances have mainly monitored elite athletes of sport modalities that require a high degree of aerobic fitness (the so-called endurance sports such as swimming, rowing, canoeing, cycling, and long-distance running). For individuals in general, a constant and moderate physical activity, characterized by the so-called "submaximal endurance training", which con- 
sists of continuous and prolonged exercise that does not exceed the anaerobic threshold in order to improve aerobic fitness, is sufficient to achieve the physiological adaptations necessary to improve such aerobic fitness. ${ }^{2}$ This is not the case for elite athletes: these have already acquired the adaptations offered by moderate training, ${ }^{95,96}$ and do not improve their aerobic fitness with an increase in the quantity of this type of training. ${ }^{97,98}$ Thus, to achieve improved exercise performance, more intense training is necessary. ${ }^{98}$ Such training is characterized by "high-intensity interval training" which consists of repeated exercise bouts of short to moderate duration (10 seconds to 5 minutes), performed at an intensity higher than the anaerobic threshold. These bouts are separated by short periods of inactivity or of lowintensity exercise, which permit partial, but generally incomplete, recovery of the athlete. The objective is to repeatedly submit the physiological systems that will be used during a certain type of endurance exercise to a situation of stress greater than that actually required during that activity $^{99}$ to achieve adaptation of these physiological systems at a level higher than that previously reached by the athlete and, consequently, to improve performance. Although the result obtained is generally as expected, the physiological mechanisms responsible for the improvement of aerobic performance following high-intensity interval training are still unknown. ${ }^{100}$

Consequently, the training season of high-level endurance athletes, which normally lasts 4 to 8 months, essentially consists of 3 different training periods: 1) a base period at the beginning of the season during which increasing quantities of mainly submaximal endurance training are employed; 2) a period during which sessions of a large quantity of submaximal endurance training are basically intercalated with sessions of high-intensity interval training, ${ }^{100}$ with the rest between training sessions not permitting complete recovery of the athlete since "superadaptation" of the organism is necessary to support the large quantity and intensity of training ${ }^{101,102}$; 3) a final period close to the competition during which training sessions are fewer and comprise lower intensity exercise to allow the athlete to rest so that he/she can reach his/her maximum potential at the time of the competition..$^{92,101}$

The studies cited above, which monitored elite athletes during their training, ${ }^{85-94}$ detected, on average or for most athletes, a worsening of mood from the first to the second training period, followed by improvement from the second to the third period, i.e., mood improved just before competition when an increase in anxiety would be expected. However, Peluso ${ }^{94}$ stated that mood changes associated with physical activity are much closer to the construct of depression than to the construct of anxiety.

\section{Overtraining syndrome}

Most athletes experience the mood deterioration observed without impairment in sport performance (in fact most of these athletes show improved performance at the end of the season). However, since in order to reach the goal of improved performance the athlete has to reach his/her limits of physical capacity (or even slightly beyond), and since the balance between desirable and excessive training is quite tenuous, ${ }^{103,104}$ the second condition, ie, excessive training (or insufficient rest), is not a rare event. In this case, the athlete starts to present more evident problems such as sleep disturbance, loss of weight and appetite, reduced libido, irritability, heavy and painful musculature, emotional lability, and even depression. ${ }^{85,101,105,106}$ The incidence of this condition among athletes is estimated to be $7 \%$ to $20 \%$ per training season, ${ }^{85,107,108}$ and this prevalence is believed to be even higher in the case of endurance sports ${ }^{109}$ and among elite athletes due to their extensive training program. Morgan and collaborators, ${ }^{110,111}$ for example, found a prevalence higher than $60 \%$ along the career of elite runners and of $38 \%$ among lower-level runners. The incidence of milder, or initial forms of the condition was estimated to be approximately $30 \%$ per training season in studies conducted on university swimmers. ${ }^{108}$

The condition described above has received different denominations such as overtraining, ${ }^{105}$ staleness, ${ }^{85}$ overstress, overuse, burnout, ${ }^{101}$ overwork, overfatigue, overstrain, ${ }^{103}$ chronic fatigue in athletes, ${ }^{112}$ sport fatigue syndrome, unexplained underperformance syndrome, ${ }^{106}$ etc. The milder or supposedly initial form of the condition has been called overreaching ${ }^{102}$ or distress. ${ }^{108}$ Overtraining syndrome was the first and continues to be the most widely used denomination.

The diagnosis of overtraining syndrome should be considered when the athlete shows a decline in sport performance following or during a period of intense training that does not improve with short-term rest ( 1 or 2 weeks), accompanied by persistent fatigue, reduced ability to perform intense training, sensation of sensitive or painful musculature, sleep disturbances, reduced libido and appetite, and mood changes such as apathy, irritability and depression, ${ }^{85,101,105,106}$ ie, a picture similar to depressive disorder. $^{35,53,85,101,103}$

In addition to these manifestations, many physiological alterations have been described; however, none of them has thus far provided a reliable single diagnostic test. ${ }^{104,113}$ Among these alterations are a reduced maximum heart rate, ${ }^{114-117}$ altered lactate measurements such as lactate concentration at maximum performance or lactate threshold, ${ }^{114,115}$ neuroendocrine alterations such as reduced noc- 
turnal norepinephrine excretion ${ }^{14,118}$ and changes in the testosterone/cortisol ratio, ${ }^{113}$ immunological alterations ${ }^{109}$ leading to infections of the upper airways, ${ }^{119}$ and changes in serum markers such as creatine kinase and urea, ${ }^{120}$ etc. However, even this large number of biological markers has not yet led to a better understanding of the etiology and physiology of overtraining syndrome. ${ }^{103,104}$

The similarity between the signs and symptoms of overtraining syndrome and depressive disorder, ${ }^{121}$ in addition to the importance of the presence of mood changes for diagnosis, ${ }^{85,101}$ led Eichner ${ }^{122}$ to suggest that overtraining syndrome is "a depression with a new face". In this respect, Armstrong and VanHeest ${ }^{103}$ more recently proposed that both syndromes have the same etiology and suggested the use of antidepressive drugs for treatment. However, this hypothesis is contradicted by the fact that some studies have shown a similar prevalence for the two sexes. ${ }^{10,111}$

Athletes suffering from overtraining syndrome generally show complete recovery after weeks or months without any other treatment than rest, ${ }^{101,123}$ which continues to be the only known treatment. ${ }^{103}$ However, this approach compromises athletes since prolonged inactivity prevents the participation in competitions of individuals who have trained for a long time and interferes with the preparation of those who plan to compete, leading to loss of motivation, loss of sponsorship, and even retirement. Therefore, the best way to deal with the condition is to prevent it. Since possible biological markers did not, and still do not permit an early diagnosis of the condition, determination of mood states has been suggested as a measure to identify over- training. ${ }^{85,86,90}$ As confirmation, subsequent studies ${ }^{91,108}$ demonstrated that a decrease in the training load of athletes with initial signs of overtraining syndrome detected by psychological monitoring of mood disturbances prevented the development of the complete syndrome, thus avoiding a period of inactivity.

\section{CONCLUSION}

Physical activity has beneficial effects for the prevention and treatment of different diseases, and evidence indicates that this assertion is probably true for psychiatric diseases such as depressive and anxiety disorders. Nevertheless, physical activity can also be harmful, especially when performed in an inappropriate or in a very intense manner (as observed in conditions as "excessive exercise" and "overtraining syndrome").

Specifically with respect to the association between physical activity and mood, evidence indicates that moderate exercise improves mood (or helps maintain it at high levels), while intense exercise leads to its deterioration, and that these mood variations are more related to the construct of depression than to the construct of anxiety.

Knowledge about the relationship between physical activity and mental health, or more specifically between physical activity and mood, is still limited; therefore, at this time, it is not possible to define the cause-effect relationship or to describe in detail the psychological and physiological mechanisms underlying this association.

\section{RESUMO}

PELUSO MAM e col. Atividade física e saúde mental: a associação entre exercício e humor. CLINICS 60(1): 61-70, 2005

A atividade física é, por seus efeitos no tratamento e na prevenção de várias patologias, um importante instrumento de saúde pública, sendo útil, inclusive, no tratamento de doenças psiquiátricas como transtornos depressivos e ansiosos. Todavia, além dos benefícios, a atividade física também está associada a prejuízos para a saúde mental, aparecendo ligada a quadros como "exercício excessivo" e "síndrome de 'overtraining", segundo alguns estudos.

Trabalhos sobre os efeitos de atividade física na saúde mental vêm se tornando mais comuns, no entanto ainda não 
permitem um conhecimento maior sobre os mecanismos implicados nos benefícios e malefícios associados a este tipo de atividade.

Este artigo procura revisar os conhecimentos disponíveis sobre as relações entre atividade física e saúde mental, principalmente no que se refere à ligação existente entre exercício e humor.

UNITERMOS: Saúde mental, humor, esporte, exercício.
1. Pate RR, Pratt M, Blair SN, Haskell WL, Macera CA, Bouchard $\mathrm{C}$, et al. Physical activity and public health: a recommendation from the Centers for Disease Control and Prevention and the American College of Sports Medicine. JAMA 1995;273(5):402-7.

2. American College of Sports Medicine. ACSM position stand: the recommended quantity and quality of exercise for developing and maintaining cardiorespiratory and muscular fitness, and flexibility in healthy adults. Med Sci Sports Exerc 1998;30(6):975-91.

3. Paffenbarger RS, Hyde RT, Wing AL, Hsieh C-C. Physical activity, all-cause mortality, and longevity of college alumni. N Engl J Med 1986;314:605-13.

4. Leon AS, Connett J, Jacobs DR Jr, Rauramaa R. Leisure-time physical activity levels and risk of coronary heart disease and death: the Multiple Risk Factor Intervention trial. JAMA 1987;258:2388-95.

5. Morris JN, Clayton DG, Everitt MG, Semmence AM, Burgess EH. Exercise in leisure time: coronary attack and death rates. Br Heart J 1990;63:325-34.

6. Paffenbarger RS, Wing AL, Hyde RT, Jung DL. Physical activity and incidence of hypertension in college alumni. Am J Epidemiol 1983;117:245-57.

7. Blair SN, Goodyear NN, Gibbons LW, Cooper KH. Physical fitness and incidence of hypertension in healthy normotensive men and women. JAMA 1984;252:487-90.

8. American College of Sports Medicine. Position stand: physical activity, physical fitness, and hypertension. Med Sci Sports Exerc 1993;10:i-x.
9. Helmrich SP, Ragland DR, Leung RW, Paffenbarger RS. Physical activity and reduced occurrence of non-insulin-dependent diabetes mellitus. N Eng1 J Med 1991;325:147-52.

10. Manson JE, Rimm EB, Stampfer MJ, Colditz GA, Willett WC, Krolewski AS, et al. Physical activity and incidence of noninsulin-dependent diabetes mellitus in women. Lancet 1991;338:774-8.

11. Manson JE, Nathan DM, Krolewski AS, Stampfer MJ, Willett WC, Hennekens CH. A prospective study of exercise and incidence of diabetes among US male physicians. JAMA 1992;268:63-7.

12. Marcus R, Drinkwater B, Dalsky G, Dufek J, Raab D, Slemenda $\mathrm{C}$, et al. Osteoporosis and exercise in women. Med Sci Sports Exerc 1992;24(Suppl):301-7.

13. Prior JC, Barr SI, Chow R, Faulkner RA. Prevention and management of osteoporosis: consensus statements from the Scientific Advisory Board of the Osteoporosis Society of Canada. 5. Physical activity as therapy for osteoporosis. CMAJ 1996;155(7):940-4.

14. Carter ND, Khan KM, McKay HA, Petit MA, Waterman C, Heinonen A, et al. Community-based exercise program reduces risk factors for falls in 65- to 75-year-old women with osteoporosis: randomized controlled trial. CMAJ 2002;167(9):997-1004.

15. Morgan WP. Affective beneficence of vigorous physical activity. Med Sci Sports Exerc 1985;17:94-100.

16. Farmer ME, Locke BZ, Moscicki EK, Dannenberg AL, Larson DB, Radloff LS. Physical activity and depressive symptoms: the NHANES I epidemiologic follow-up study. Am J Epidemiol 1988;128:1340-51. 
17. Martinsen EW, Hoffart A, Solberg O. Aerobic and non-aerobic forms of exercise in the treatment of anxiety disorders. Stress Med 1989;5:115-20.

18. Martinsen EW, Hoffart A, Solberg O. Comparing aerobic with nonaerobic forms of exercise in the treatment of clinical depression: a randomized trial. Compr Psychiatry $1989 ; 30(4): 324-31$

19. Raglin JS. Exercise and mental health. Beneficial and detrimental effects. Sports Med 1990;9(6):323-9.

20. North TC, McCullagh P, Tran ZV. Effect of exercise on depression. Exerc Sport Sci Rev 1990;18:379-415.

21. Petruzzello SJ, Landers DM, Hatfield BD, Kubitz KA, Salazar W. A meta-analysis of the anxiety-reducing effects of acute and chronic exercise. Outcomes and mechanisms. Sports Med $1991 ; 11(3): 143-82$.

22. Martinsen EW. Physical activity and depression: clinical experience. Acta Psychiatr Scand 1994;377 Suppl:23-7.

23. Dimeo F, Bauer M, Varahram I, Proest G, Halter U. Benefits from aerobic exercise in patients with major depression: a pilot study. Br J Sports Med 2001;35(2):114-7.

24. Dunn AL, Trivedi MH, O’Neal HA. Physical activity doseresponse effects on outcomes of depression and anxiety. Med Sci Sports Exerc 2001;33(6 Suppl):587-97.

25. Leppamaki SJ, Partonen TT, Hurme J, Haukka JK, Lonnqvist JK. Randomized trial of the efficacy of bright-light exposure and aerobic exercise on depressive symptoms and serum lipids. J Clin Psychiatry 2002;63(4):316-21.

26. Camacho TC, Roberts RE, Lazarus NB, Kaplan GA, Cohen RD Physical activity and depression: evidence from the Alameda County study. Am J Epidemiol 1991;134:220-31.

27. Paffenbarger RS, Lee IM, Leung R. Physical activity and personal characteristics associated with depression and suicide in American college men. Acta Psychiatr Scand Suppl 1994;377:16-22.

28. Gartenmann Ch, Kirchberger I, Herzig M, Baumgartner I, Saner H, Mahler F, Meyer K. Effects of exercise training program on functional capacity and quality of life in patients with peripheral arterial occlusive disease. Evaluation of a pilot project. Vasa 2002;31(1):29-34.

29. Gowans SE, deHueck A, Voss S, Silaj A, Abbey SE, Reynolds WJ. Effect of a randomized, controlled trial of exercise on mood and physical function in individuals with fibromyalgia. Arthritis Rheum 2001;45(6):519-29.

30. Ussher M, Nunziata P, Cropley M, West R. Effect of a short bout of exercise on tobacco withdrawal symptoms and desire to smoke. Psychopharmacology (Berl.2001;158(1):66-72.

31. Slaven L, Lee C. Mood and symptom reporting among middleaged women: the relationship between menopausal status, hormone replacement therapy, and exercise participation. Health Psychol 1997;16(3):203-8.

32. Dua J, Hargreaves L. Effect of aerobic exercise on negative affect, positive affect, stress, and depression. Percept Mot Skills 1992;75:355-61.
33. Kritz-Silverstein D, Barrett-Connor E, Corbeau C. Cross-sectional and prospective study of exercise and depressed mood in the elderly: the Rancho Bernardo study. Am J Epidemiol 2001;153(6):596-603.

34. Sexton H, Sogaard AJ, Olstad R. How are mood and exercise related? Results from the Finnmark study. Soc Psychiatry Psychiatr Epidemiol 2001;36(7):348-53.

35. Paluska SA, Schwenk TL. Physical activity and mental health: current concepts. Sports Med 2000;29(3):167-80.

36. Engels HJ, Currie JS, Lueck CC, Wirth JC. Bench/step training with and without extremity loading. Effects on muscular fitness, body composition profile, and psychological affect. J Sports Med Phys Fitness 2002;42(1):71-8.

37. Sonstroem RJ, Morgan WP. Exercise and self-esteem rationale and model. Med Sci Sports Exerc 1989;21:329-37.

38. Salmon P. Effects of physical exercise on anxiety, depression, and sensitivity to stress: a unifying theory. Clin Psychol Rev 2001;21(1):33-61

39. Brosse AL, Sheets ES, Lett HS, Blumenthal JA. Exercise and the treatment of clinical depression in adults: recent findings and future directions. Sports Med 2002;32(12):741-60.

40. Maroulakis E, Zervas Y. Effects of aerobic exercise on mood of adult women. Percept Mot Skills 1993;76:795-801.

41. Yeung RR. The acute effects of exercise on mood state. J Psychosom Res 1996;2:123-41.

42. Berger BG, Grove JR, Prapavessis H, Butki BD. Relationship of swimming distance, expectancy, and performance to mood states of competitive athletes. Percept Mot Skills 1997;84(3 Pt 2):1199-210

43. Hansen CJ, Stevens LC, Coast JR. Exercise duration and mood state: how much is enough to feel better? Health Psychol 2001;20(4):267-75.

44. Rehor PR, Dunnagan T, Stewart C, Cooley D. Alteration of mood state after a single bout of noncompetitive and competitive exercise programs. Percept Mot Skills 2001;93(1):249-56.

45. Williamson D, Dewey A, Steinberg H. Mood change through physical exercise in nine- to ten-year-old children. Percept Mot Skills 2001;93(1):311-6.

46. Raglin JS, Morgan WP. Influence of exercise and quiet rest on state anxiety and blood pressure. Med Sci Sports Exerc $1987 ; 19: 456-83$

47. Brown DR, Morgan WP, Raglin JS. Effects of exercise and rest on the state anxiety and blood pressure of physically challenged college students. J Sports Med Phys Fitness 1993;33(3):3005 .

48. Biddle S. Exercise and psychosocial health. Res Q Exerc Sport 1995;66(4):292-7.

49. Koltyn KF, Raglin JS, O'Connor PJ, Morgan WP. Influence of weight training on state anxiety, body awareness and blood pressure. Int J Sports Med 1995;16(4):266-9. 
50. Focht BC, Koltyn KF. Influence of resistance exercise of different intensities on state anxiety and blood pressure. Med Sci Sports Exerc 1999;31(3):456-63.

51. Ransford CP. A role for amines in the antidepressant effect of exercise: a review. Med Sci Sports Exerc 1982;4(1):1-10.

52. Dunn AL, Dishman RK. Exercise and the neurobiology of depression. Exerc Sport Sci Rev 1991;19:41-98.

53. Nicoloff G, Schwenk TS. Using exercise to ward off depression. Phys Sportsmed 1995;23(9):44-58.

54. Allen M. The psychobiology of athletic training. In: Begel D, Burton RW, editors. Sport psychiatry: theory and practice. New York: W. W. Norton \& Company; 2000. p. 22-44.

55. Morris M, Steinberg H, Sykes EA, Salmon P. Effects of temporary withdrawal from regular running. J Psychosom Res 1990;34:493-500.

56. Jarvekulg A, Viru A. Opioid receptor blockade eliminates mood effects of aerobic gymnastics. Int $\mathrm{J}$ Sports Med $2002 ; 23(3): 155-7$.

57. Thoren P, Floras JS, Hoffmann P, Seals DR. Endorphins and exercise: physiological mechanisms and clinical implications. Med Sci Sports Exerc 1990;22(4):417-28.

58. Greenspan M, Fitzsimmons P, Biddle S. Aspects of psychology in sports medicine. Br J Sports Med 1991;25(4):178-80.

59. Spieker MR. Exercise dependence in a pregnant runner. J Am Board Fam Pract 1996;9(2):118-21

60. Bamber D, Cockerill IM, Carroll D. The pathological status of exercise dependence. Br J Sports Med 2000;34(2):125-32.

61. Yates A, Leehey K, Shisslak CM. Running: an analogue of anorexia? N Engl J Med 1983;308:251-5.

62. de Coverly Veale DMW. Exercise dependence. Br J Addict 1987;87:735-40.

63. Blumenthal JA, O'Toole LL, Chang JL. Is running an analogue of anorexia nervosa? An empirical study of obligatory running and anorexia nervosa. JAMA 1984;252:520-3.

64. Davis C, Fox J. Excessive exercise and weight preoccupation in women. Addict Behav 1993;18(2):201-11.

65. Anderson SJ, Basson CJ, Geils C. Personality style and mood states associated with a negative addiction to running. Sports Med 1997;4:6-11.

66. Taylor WN. Hormonal manipulation: a new era of monstrous athletes. Jefferson (NC): McFarland; 1985.

67. Pope HG Jr, Katz DL, Hudson JI. Anorexia nervosa and "reverse anorexia" among 108 male bodybuilders. Compr Psychiatry 1993;34:406-9.

68. Blouin AG, Goldfield GS. Body image and steroid use in male bodybuilders. Int J Eating Disord 1995;18:159-65.

69. Drewnowski A, Kurth CL, Krah DD. Effects of body image on dieting, exercise, and anabolic steroid use in adolescent males. Int J Eat Disord 1995;17:381-6.
70. Pope HG Jr, Gruber AJ, Choi P, Olivardia R, Phillips K. Muscle dysmorphia: an underrecognized form of body dysmorphic disorder. Psychosomatics 1997;38:548-557.

71. Olivardia R, Pope, Harrison G Jr, Hudson JI. Muscle dysmorphia in male weightlifters': a case-control study. Am J Psychiatry 2000;157(8):1291-6

72. American Psychiatric Association. Diagnostic and statistical manual of mental disorders. $4^{\text {th }}$ ed. Washington (DC): American Psychiatric Association; 1994.

73. Pope HG Jr, Kouri EM, Powell KF, Campbell C, Katz DL. Anabolic-androgenic steroid use among 133 prisoners. Compr Psychiatry 1996;37:322-7.

74. Pope HG Jr, Katz DL. Affective and psychotic symptoms associated with anabolic steroid use. Am J Psychiatry 1988;145:487-90.

75. Perry PJ, Yates WR, Andersen KH. Psychiatric symptoms associated with anabolic steroids: a controlled, retrospective study. Ann Clin Psychiatry 1990;2:11-7.

76. Bahrke MS, Wright JE, Strauss RH, Catlin DH. Psychological moods and subjectively perceived behavioral and somatic changes accompanying anabolic-androgenic steroid use. Am J Sports Med 1992;20:717-24.

77. Pope HG Jr, Katz DL. Psychiatric and medical effects of anabolicandrogenic steroid use: a controlled study of 160 athletes. Arch Gen Psychiatry 1994;51:375-82.

78. Peluso MA, Assunção S, Araújo LA, Andrade L. Alterações psiquiátricas associadas ao uso de anabolizantes. Rev Psiquiat Clín 2000;27(4): 229-36.

79. Brower KJ. Anabolic steroids. Psychiatr Clin North Am $1993 ; 16: 97-103$

80. Koltyn KF, Lynch NA, Hill DW. Psychological responses to brief exhaustive cycling exercise in the morning and the evening. Int J Sport Psychol 1998;29(2):145-56.

81. Blanchard CM, Rodgers WM, Spence JC, Courneya KS. Feeling state responses to acute exercise of high and low intensity. J Sci Med Sport 2001;4(1):30-8

82. Oweis P, Spinks W. Biopsychological, affective and cognitive responses to acute physical activity. J Sports Med Phys Fitness $2001 ; 41(4): 528-38$

83. O'Connor PJ, Morgan WP, Raglin JS. Psychobiologic effects of $3 \mathrm{~d}$ of increased training in female and male swimmers. Med Sci Sports Exerc 1991;23(9):1055-61.

84. Shephard RJ. Absolute versus relative intensity of physical activity in a dose-response context. Med Sci Sports Exerc 2001;33(6 Suppl):400-18.

85. Morgan WP, Brown DR, Raglin JS, O'Connor PJ, Ellickson KA Psychological monitoring of overtraining and staleness. Br J Sports Med 1987;21(3):107-14

86. Morgan WP, Costill DL, Flynn MG, Raglin JS, O’Connor PJ. Mood disturbance following increased training in swimmers Med Sci Sports Exerc 1988;20(4):408-14. 
87. O'Connor PJ, Morgan WP, Raglin JS, Barksdale CM, Kalin NH. Mood state and salivary cortisol levels following overtraining in female swimmers. Psychoneuroendocrinology 1989;14(4):303-10

88. Raglin JS, Morgan WP, Luchsinger AE. Mood state and selfmotivation in successful and unsuccessful women rowers. Med Sci Sports Exerc 1990;22:849-53.

89. Raglin JS, Morgan WP, O'Connor PJ. Changes in mood states during training in female and male college swimmers. Int J Sports Med 1991;12:585-9.

90. Verde T, Thomas SC, Shephard RJ. Potential markers of heavy training in highly trained distance runners. Br J Sports Med $1992 ; 26: 167-75$

91. Berglund B, Safstrom H. Psychological monitoring and modulation of training load of world-class canoeists. Med Sci Sports Exerc 1994;26(8):1036-40.

92. Raglin JS, Koceja DM, Stager JM, Harms CA. Mood, neuromuscular function, and performance during training in female swimmers. Med Sci Sports Exerc 1996;28(3):372-7.

93. Steinacker JM, Lormes W, Kellmann M, Liu Y, Reissnecker S, Opitz-Gress A, et al. Training of junior rowers before world championships. Effects on performance, mood state and selected hormonal and metabolic responses. J Sports Med Phys Fitness 2000;40(4):327-35.

94. Peluso MA. Alterações de humor associadas a atividade física intensa. (Tese de doutorado). São Paulo: Universidade de São Paulo; 2003.

95. Jones AM, Carter $\mathrm{H}$. The effect of endurance training on parameters of aerobic fitness. Sports Med 2000;29:373-86.

96. Laursen PB, Rhodes EC. Factors affecting performance in an ultraendurance triathlon. Sports Med 2001;31:195-209.

97. Lake MJ, Cavanagh PR. Six weeks of training does not change running mechanics or improve running economy. Med Sci Sports Exerc 1996;28:860-9.

98. Londeree BR. Effect of training on lactate/ventilatory thresholds: a meta-analysis. Med Sci Sports Exerc 1997;29:837-43.

99. Daniels J, Scardina N. Interval training and performance. Sports Med 1984;1:327-34.

100. Laursen PB, Jenkins DG. The scientific basis for high-intensity interval training: optimising training programmes and maximising performance in highly trained endurance athletes. Sports Med 2002;32(1):53-73.

101. Raglin JS. Overtraining and staleness: Psychometric monitoring of endurance athletes. In: Singer RB, Murphey M, Tennart LK (Eds.). Handbook of Research on Sport Psychology. New York: Macmillan; 1993.

102. Kuipers H. Training and overtraining: an introduction. Med Sci Sports Exerc 1998;30(7):1137-9.

103. Armstrong LE, VanHeest JL. The unknown mechanism of the overtraining syndrome: clues from depression and psychoneuroimmunology. Sports Med 2002;32(3):185-209.
104. Petibois C, Cazorla G, Poortmans JR, Deleris G. Biochemical aspects of overtraining in endurance sports: a review. Sports Med 2002;32(13):867-78

105. Budgett R. Overtraining syndrome. Br J Sports Med 1990;24(4):231-6.

106. Budgett R, Newsholme E, Lehmann M, Sharp C, Jones D, Jones $\mathrm{T}$, et al. Redefining the overtraining syndrome as the unexplained underperformance syndrome. Br J Sports Med 2000;34(1):67-8

107. Hooper SL, Mackinnon LT, Gordon RD, Bachmann AW. Hormonal responses of elite swimmers to overtraining. Med Sci Sports Exerc 1993;25:741-7.

108. Raglin JS, Morgan WP. Development of a scale for use in monitoring training-induced distress in athletes. Int $\mathrm{J}$ Sports Med 1994;15(2):84-8

109. Mackinnon LT. Overtraining effects on immunity and performance in athletes. Immunol Cell Biol 2000;78(5):5029.

110. Morgan WP, O'Connor PJ, Sparling PB, Pate RR. Psychologic characterization of the elite female distance runner. Int J Sports Med 1987;8:124-31

111. Morgan WP, O'Connor PJ, Ellickson KA, Bradley PW. Personality structure, mood states, and performance in elite male distance runners. Int J Sport Psychol 1988;19:247-63.

112. Smith C, Kibry P, Noakes TD. The worn out athlete: a clinical approach to chronic fatigue in athletes. J Sports Sci 1997; 15:341-51.

113. Urhausen A, Kindermann W. Diagnosis of overtraining: what tools do we have? Sports Med 2002;32(2):95-102.

114. Lehmann M, Schnee W, Scheu R, Stockhausen W, Bacl N. Decreased nocturnal catecholamine excretion: parameter for an overtraining syndrome in athletes. Int J Sports Med $1992 ; 13: 236-42$

115. Snyder AC, Kuipers H, Cheng B, Servais RM, Fransen E. Overtraining following intensified training with normal muscle glycogen. Med Sci Sports Exerc 1995;27:1063-70.

116. Urhausen A, Gabriel HH, Welier B, Kindermann W. Ergometric and psychological findings during overtraining: a long-term follow-up study in endurance athletes. Int J Sports Med 1998;19:114-20

117. Zavorsky GS. Evidence and possible mechanisms of altered maximum heart rate with endurance training and tapering. Sports Med 2000;29:13-26.

118. Mackinnon LT, Hooper SL, Jones S, Gordon RD, Bachmann AW. Hormonal, immunological, and hematological responses to intensified training in swimmers. Med Sci Sports Exerc 1997;29:1637-45.

119. Foster C. Monitoring training in athletes with reference to overtraining syndrome. Med Sci Sports Exerc 1998;30(7):1164-8. 
120. Hartmann U, Mester J. Training and overtraining markers in selected sport events. Med Sci Sports Exerc 2000;32(1):20915 .

121. Organização Mundial de Saúde. Classificação de Transtornos Mentais da CID-10 - Descrições Clínicas e Diretrizes Diagnósticas. Porto Alegre: Artes Médicas; 1993.
122. Eichner E. Chronic fatigue syndrome: searching for the cause and treatment. Phys Sportsmed 1989;17(6):142-52.

123. Koutedakis Y, Budgett R, Faulmann L. Rest in underperforming elite athletes. Br J Sports Med 1990;24(4):248-52. 